九州大学学術情報リポジトリ

Kyushu University Institutional Repository

\title{
Development of a Ubiquitous Information Technology Based Distribution Traceability Management System for Imported Beef in Korea
}

Lee, Kang Oh

Foodsafety team, Korea Information Center for Agriculture, Forestry and Fisheries

Woo, Myeong Ho

Foodsafety team, Korea Information Center for Agriculture, Forestry and Fisheries

Nakaji, Ke i

Laboratory of Agricultural Ecology, Division of Agronomy \& Environmental Sciences, Department of Agro-environmental Sciences, Faculty of Agriculture, Kyushu University

https://doi.org/10.5109/19539

出版情報: 九州大学大学院農学研究院紀要. 56 (1)，pp.115-122，2011-02. Faculty of Agriculture， Kyushu University

バージョン :

権利関係 : 


\title{
Development of a Ubiquitous Information Technology Based Distribution Traceability Management System for Imported Beef in Korea
}

\author{
Kang Oh LEE ${ }^{1 *}$, Myeong Ho WOO ${ }^{1}$ and Kei NAKAJI ${ }^{2}$ \\ ${ }^{1}$ Foodsafety team, Korea Information Center for Agriculture, Forestry and Fisheries, Korea \\ ${ }^{2}$ Laboratory of Agricultural Ecology, Division of Agronomy \& Environmental Sciences, \\ Department of Agro-environmental Sciences, Faculty of Agriculture, \\ Kyushu University, Fukuoka 811-2307, Japan \\ (Received October 29, 2010 and accepted November 8, 2010)
}

\begin{abstract}
A distribution traceability management system for imported beef based on ubiquitous information technology (u-IT) was developed by the Ministry for Food, Agriculture, Forestry and Fisheries in Korea to manage the distribution traceability and to trade reliable beef. The system was developed for the seller, government official, and consumer, separately by considering users' convenience. Distributors of imported beef registered and managed the distribution traceability on the computerized system, and government officials could monitor distribution managements and deal with recall immediately when the beef at risk was alerted. The information for the imported risk beef is rapidly transferred by the Sort Message Service (SMS), and sales of beef can be prevented by an electronic balance based on u-IT or by a credit card terminal. The developed system will be broadly used from December 2010 after testing the system within restricted areas as a model.
\end{abstract}

\section{INTRODUCTION}

The interests in safe foods become greater due to improved living standards and priority for health. Increased international trades after Uruguay round and FTA are demanding for the food safety in imported products as well as domestic ones. Korean government is trying to fortify regulations and laws to assure food safety such as certification for food safety, a mark of the origin, traceability management, strengthened inspection for the imported foods, etc. Particularly, the decision of importing the US beef products followed by the South Korea-United States FTA in 2008 spring ignited nationwide candle light protests in Korea. This protest has shown serious concerns about Bovine Spongiform Encephalopathy (BSE) from the public and has enforced Korean government to eliminate concerns of the public by establishing the systematic safety management and to recover trust in the government.

The purpose of the traceability system is understanding the growth and management information of each animal, finding out causes, and recalling the product when the food accidents happen by tracing distribution of the product (MAF, 2005). The traceability system for cows was broadly introduced after the risk of BSE. This system was started from EU and is widely distributed and used in Australia, Japan, and United States. The record and management of production and distribution by traceability are prepared for the risk management (Huh du, 2008).

${ }^{1}$ Foodsafety team, Korea Information Center for Agriculture, Forestry and Fisheries, Korea

${ }^{2}$ Laboratory of Agricultural Ecology, Division of Agronomy \& Environmental Sciences, Department of Agro-environmental Sciences, Faculty of Agriculture, Kyushu University, Fukuoka 811-2307, Japan

* Corresponding author (E-mail: leeko2@affis.net)
Domestic beef traceability management system was introduced in 2004 and has been used after a demonstration project (MIFAFF, 2010a). A system to manage distribution information was established from customs clearance, processing, distribution, and selling. However, there were many problems in management of products, registration of the products, participation of sellers, etc. (MIFAFF, 2010b). While the traceability for domestic beef has been adjusted, a development of the system for imported beef which can manage distribution information at each step of transactions and can recall the beef immediately is required because of increasing trends of livestock import (Gallup Korea, 2010).

We developed a ubiquitous information technology (u-IT) based distribution traceability system to guarantee the faithfulness of imported beef distribution and to manage food safety systematically. This traceability system can be used by seller, public officer, and consumer, individually. Distribution traceability information of imported beef can be checked through the internet, can prevent sales, and can recall the risk beef fast.

\section{MATERIALS AND METHODS}

\section{Development of a distribution traceability sys- tem for imported beef}

Distribution traceability for imported beef is a reliable system of distribution traceability management, which means that beef products importers report and computerize all transactions occurred in each distribution stage from import to sales to consumers. In addition, consumers can check the distribution traceability information of imported beef anytime through the internet and mobile. The system was developed for three different subjects, i.e., the seller, public official, and consumer. Each subject can utilize one module of the system specialized for each of them. Registration required 


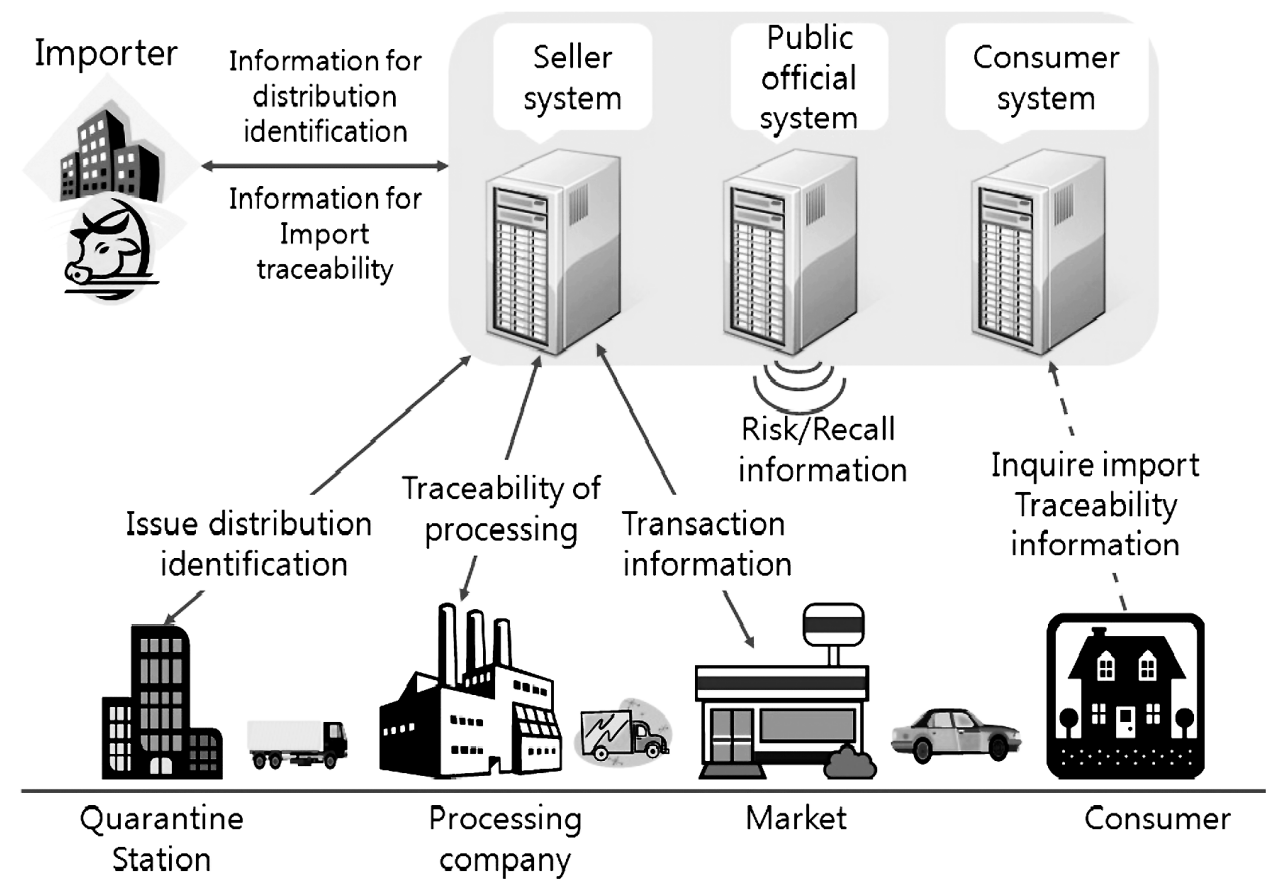

Fig. 1. Structure diagram of a u-IT based distribution traceability management system for imported beef.

sellers are importers, people working in the company of wrapping beef products, and people selling meat and byproducts of beef.

There are four department and institutes involved in the distribution traceability system; Ministry for Food, Agriculture, Forestry and Fisheries (MIFAFF) takes overall responsibilities of the distribution traceability system, National Veterinary Research \& Quarantine Service (NVRQS) plays a role of actual operation of the system, and Korea Information Center for Agriculture, Forestry and Fisheries (KICAFF) and Livestock Health Control Association (LHCA) assist for the system operation.

\section{Distribution traceability management for imported beef and work flow chart}

Fig. 2 shows a work flow chart of distribution traceability management. Distributors of imported beef apply for the identification number of imported products distribution, attach the issued identification number to the box of imported beef products, and then proceed with an import declaration for goods.

When the imported beef product with the identification number of distribution is on sale, it is required for distributors of the imported beef product to report all transactions electronically by connecting to the distribution traceability management system for imported

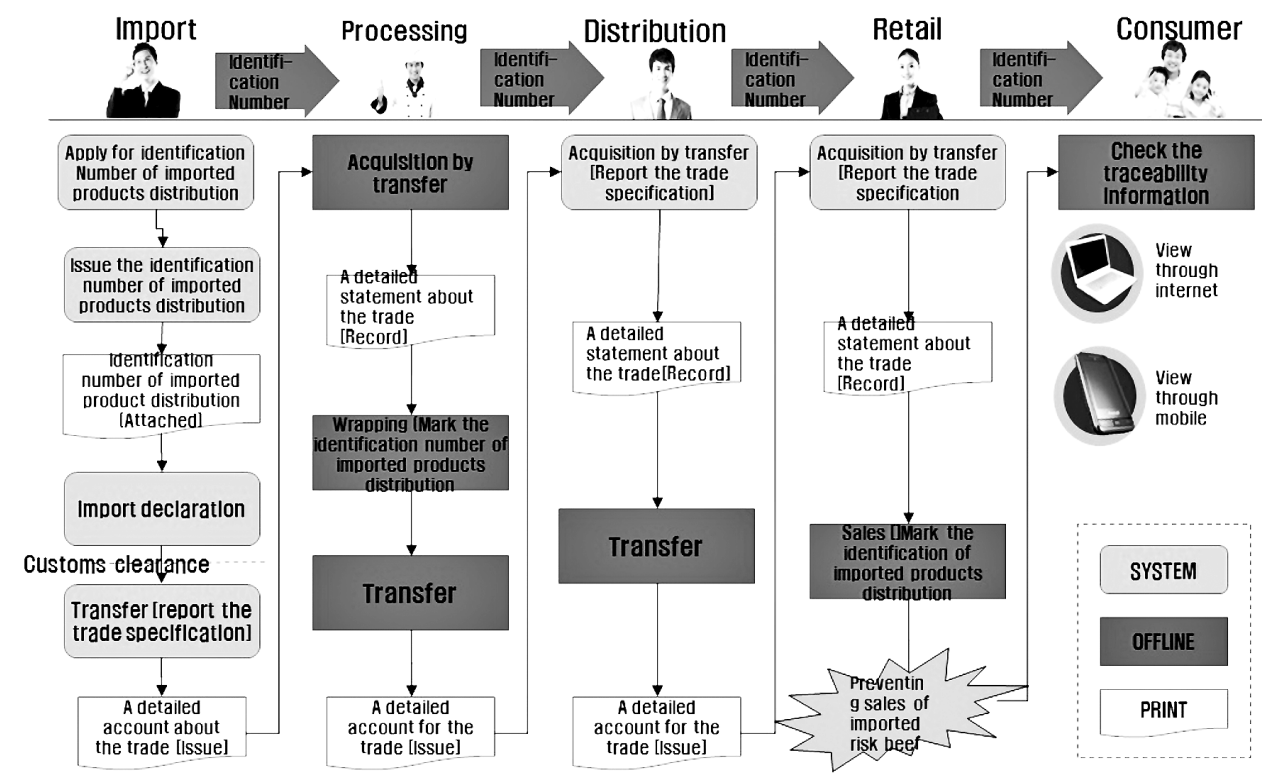

Fig. 2. Work flowchart of the distribution traceability management system. 
beef. In case there is any change on the form of distribution management for the imported goods, people working on wrapping meat and salesmen for meat and byproducts need to submit another form to notify the change.

Consumers can check the distribution traceability information for imported beef anytime by connecting to the distribution traceability management system. Risk beef is monitored and managed by relevant public officials and is prevented from sales by the u-IT applied electronic balance and a credit card terminal at the sales stage.

\section{A survey for recognition and attitudes about the system to general consumers and domestic cow farmers}

The general thoughts for imported beef were surveyed by a professional survey institute. Surveyed subjects were composed of one thousand of general consumers selected by 3-stage stratified random sampling in proportion to the population in area and three hundred of domestic cow farmers selected by random sampling. A telephone survey was conducted by using structured questionnaires from December $21^{\text {st }}$ to $28^{\text {th }}$ in 2009.

\section{1) Purchasing beef}

Frequency of buying beef in general family was "less than once a month (37.3\%)" or "1-2 times a month (32.9\%)". The most popular type of beef purchased was domestic beef depending on the situation (52.5\%), and then "always domestic beef (41.2\%)" was followed after (Fig. 3).

Among responders, the age group of 30-40 showed that "always domestic beef" was relatively higher than the others. The percentage of imported beef purchasing was higher for people in the metropolitan area than for the local residents.

\section{2) Needs and interests for the introduction of a dis- tribution traceability management system for imported beef products}

After explaining a distribution traceability management system for imported beef to the general, $41.1 \%$ of responders already recognized the system. With regard to the need for the introduction of a distribution traceability management system for imported beef products, $91.1 \%$ of the general (51.2\% of 'strongly required' and $39.9 \%$ of 'required') were positive for the system (Fig. 4(a)). Among cow farmers, $84.3 \%$ of responders agreed to the introduction of the system $(71.3 \%$ of 'strongly

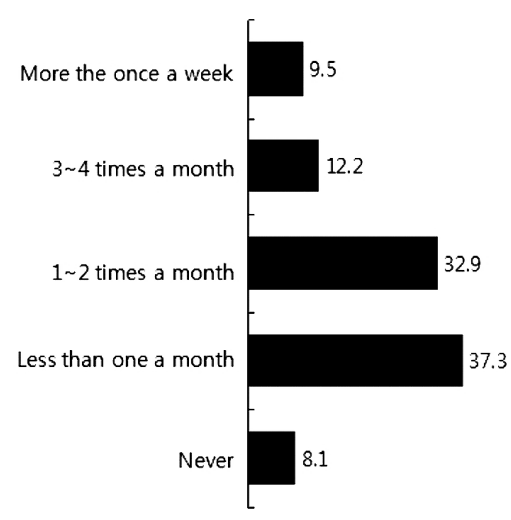

(a) Frequency of purchasing beef
(\%)

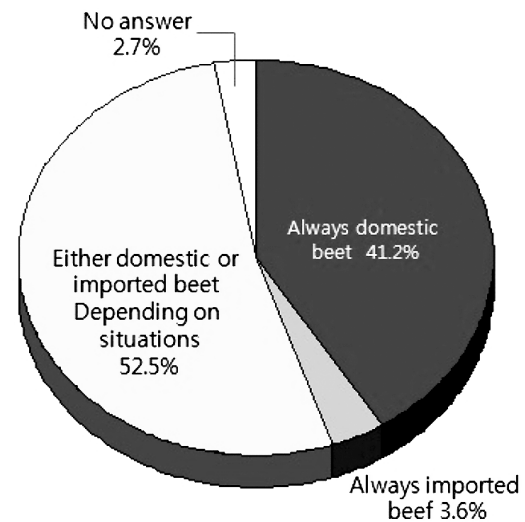

(b) Type of purchasing beef

Fig. 3. Purchasing beef by general consumers.

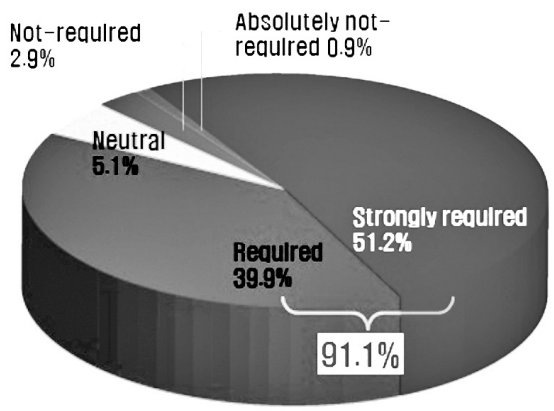

(a) General consumer

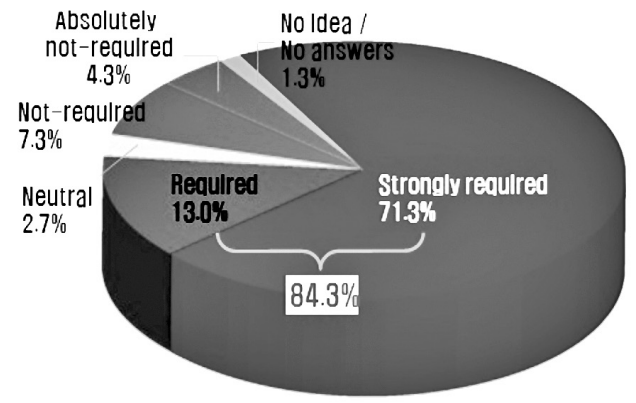

(b) Domestic cow farm

Fig. 4. Necessity for the introduction of the distribution traceability management system for imported beef. 


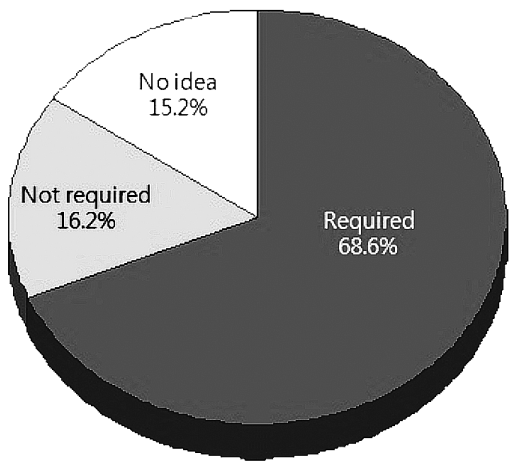

(a) Necessity for opening distribution information

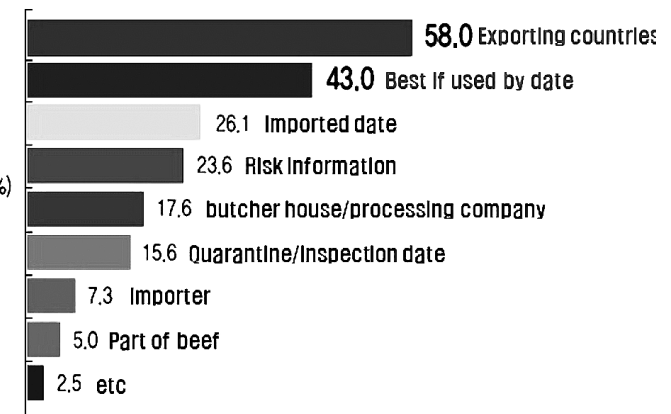

(b) Information of interest

Fig. 5. Opening the information of the distribution traceability management system for imported beef and information of interest.

required' and $13.0 \%$ of 'required'). The $68.6 \%$ of responders thought that it is needed to open the information of imported beef distribution throughout the system. The information in which consumers are interested was in order of "exporting country (58\%)", "Best if used by date (43\%)", "importer (26.1\%), and risk beef (23.6\%)" (Fig. 5).

\section{RESULTS AND DISCUSSION}

\section{Development of a u-IT based distribution tracea- bility management system}

Development of a u-IT based distribution traceability management system is one of the $\mathrm{u}$-IT facilitation projects by the Ministry of Knowledge Economy. Distribution traceability efficiency for imported beef and the Information Strategy Planning (ISP) were estab- lished from October 2008 to March 2009, and the system development had been completed from August 2009 to March 2010.

A u-IT based distribution traceability management system was developed with a consideration of importers' convenience, application of information technology by using as radio-frequency identification (RFID), compatibility with domestic cow identification number, etc. The server for this system was located in Gwangju Internet Data Center (IDC). Relevant institutes, a chair of the quarantine station, distributor, large sellers, and consumers can access to the system through administration network and the internet (Fig. 6).

Major developed systems are for consumers' portal, sellers, public officials, RFID infra, management of issuing a tag, and a linkage among related institutes.

The system for consumers' portal (http://www.meat-

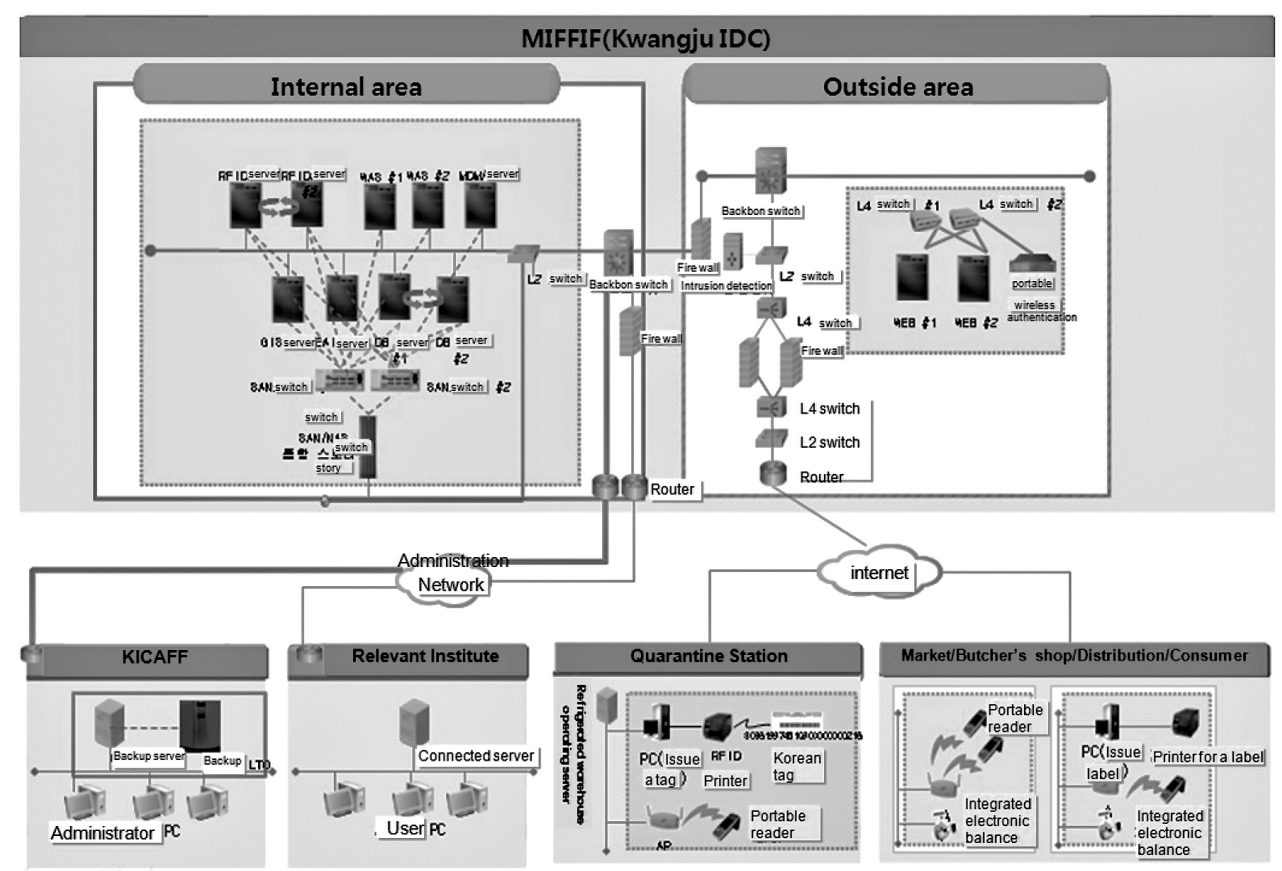

Fig. 6. Composition diagram of the distribution traceability management system for imported beef. 
watch.go.kr) provides the country of origin and distribution traceability information for imported beef to reduce consumers' concerns and to satisfy consumers' right to know. This system is composed of import traceability information, current import statistics, related laws and regulations, education materials, and community service.

Cyber tour provides opportunities to experience the way of traceability management in each distribution stage through the on-line simulation (Fig. 7). Sellers and public officials can mange information on the separate screen by clicking "MENU" on top of the right. They can also easily check the distribution traceability information of the imported beef bought by consumers.

The system for sellers was developed in each distribution stage. Importers can register distribution identification information for imported goods by using import declaration for livestock products in the quarantine/ inspection information system, civil petition system on the internet, and electronic customs clearance. The distribution identification number for imported goods can be applied and get issued through the sellers' system. In addition, warehousing and delivery information of the imported beef is systematically managed, and it is possible to manage the traceability information because the distribution identification number for imported goods is re-issued and attached on the box used in wrapping. At the selling stage, when the products are stocked in the market, reporting automatic warehousing and electronic transaction, and issuing a tag are the available functions. Fig. 8 shows a generator of barcode for distribution identification number of imported beef and the photo of attaching the barcode.

The system for public officials was developed to support fast recalling under the situation of risk beef occurrence and has six functions: recall management for imported and domestic livestock, distribution pathways monitoring, conversion to freezing, sanitation, statistics and search.

Recall (domestic and imported products) is sepa-

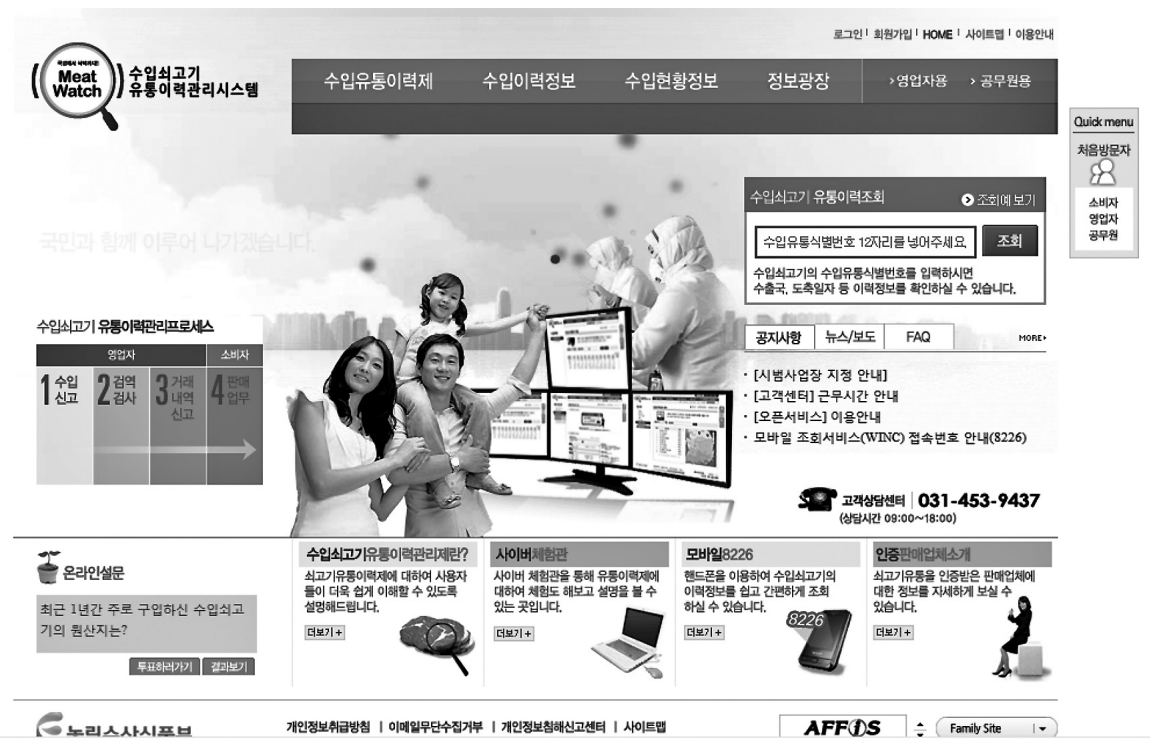

Fig. 7. Main screen of the distribution traceability management system for imported beef.

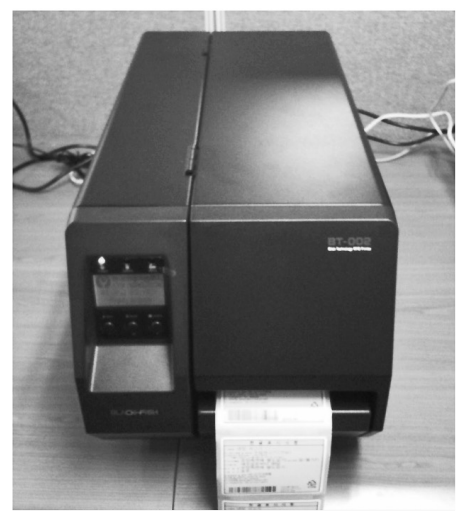

(a) Issue the barcode of the distribution identification number

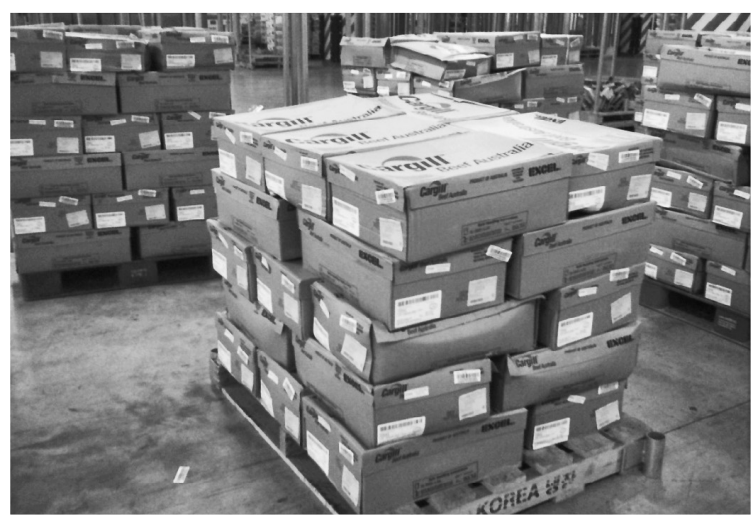

(b) Attach the distribution identification number to the box

Fig. 8. Photos of issuing and attaching the distribution identification number. 


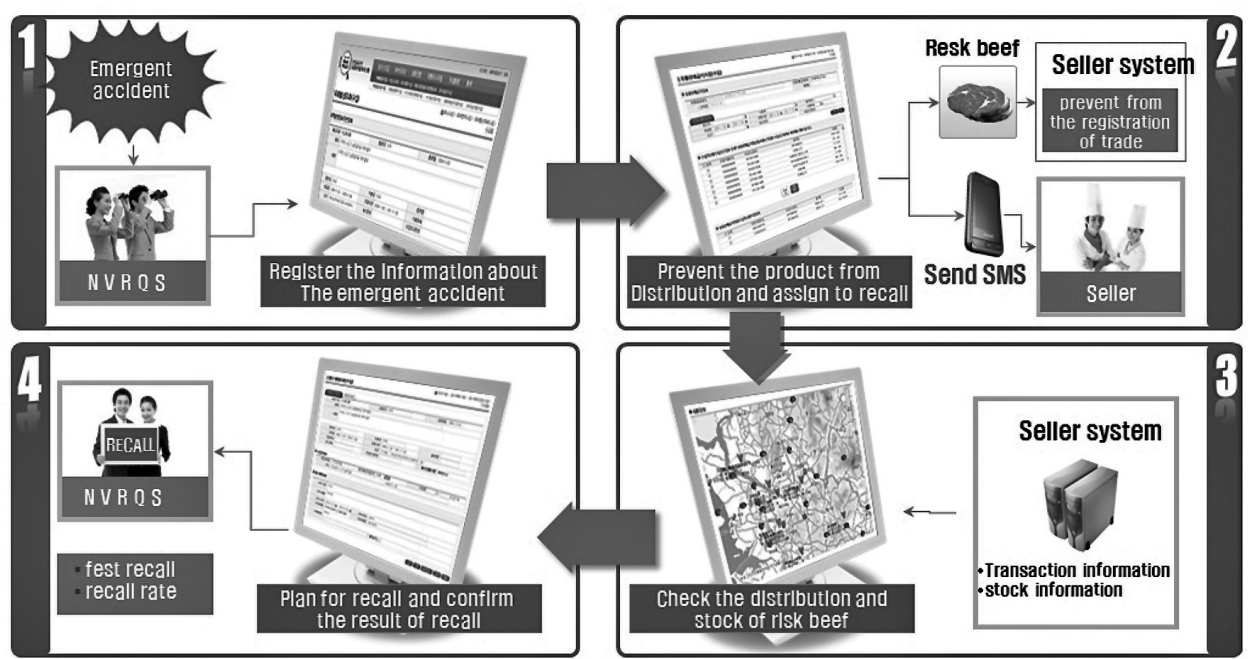

Fig. 9. Provide recall information fast through the GIS based monitoring.

rately managed on the basis of origin of the livestock; imported products and domestic products are managed by NVRQS and local department, respectively.

Particularly, the occurrence of risk beef imported can be treated fast by designation of subjects for inspection to prevent from distribution and sales and to recall. Additionally, under the occurrence of risk beef, the emergent situation is delivered through Sort Message Service (SMS), and distribution of the risk beef in real time and the amount of remaining stocks can be checked.

Real-time transactions and storage through the Geographic Information Systems (GIS) can be checked by the monitoring function of distribution traceability management. Stock index based on the average period of consumption per item is calculated, and this stock index is used for detecting the market which has high probability of illegal distribution. Fig. 9 is a work flow providing recall information for risk beef and checking recall plans and results through the GIS based monitoring.

\section{Functions for inquiring distribution traceability and for preventing from sales of risk beef}

Consumers can inquire distribution traceability information about imported beef with a connection of the distribution traceability management system. After clicking the menu "import traceability information" on the top and typing a 12-digit number of distribution identification for imported goods, consumers can check detail information such as origin of the country, exporting company, butcher house, processing company, dates of processing, best if used by date.

By the mobile service, the number of [6626] which is same as for domestic beef is used to check traceability information of imported beef. As a first step, 56 quarantine stations, 2 big markets, 1 butcher's shop and 2 distribution companies are participating in operation of the developed system (Table 1). The period of operating system as a model is from March to December in 2010.

The recall of risk beef means preventing from dis-
Table 1. Stations and companies participating in the system operation as a model (October 2010)

\begin{tabular}{lcl}
\hline Classification & Number & Participating stations and companies \\
\hline $\begin{array}{l}\text { Quarantine } \\
\text { station }\end{array}$ & 56 & 56 quarantine/inspection stations \\
$\begin{array}{l}\text { Big market } \\
\text { (Storage) }\end{array}$ & $2(3)$ & E-mart (1)-Storage (3), Galleria \\
$\begin{array}{l}\text { Butcher's } \\
\text { shop }\end{array}$ & 1 & Meat store \\
$\begin{array}{l}\text { Distribution } \\
\text { company }\end{array}$ & 2 & Korean-Chinese food \\
\hline
\end{tabular}

tribution/sales and returning risk beef which is infected by pathogens or contaminated to risk materials designated by the Minister of MIFAFF so that it is harmful to human beings' health. Under the circumstance of risk beef, the public officials who are in charge of recall register the identification distribution number of the risk beef and inform this occurrence to relevant people through the SMS service. An electronic balance and a credit card terminal get the information of risk beef in the market, and thus the sales is prevented because the label is not printed from the electronic balance, and transaction receipt is not issued from the credit card terminal (Fig. 10).

\section{Distribution traceability management system for imported beef and RFID management system}

A management system using several automated identification facilities such RFID was developed to minimize workloads and to mange transaction information together effectively because scientific and objective methods were required to collect distribution pathways information of imported beef.

To manage distribution traceability for imported beef, the distribution identification number for the imported good was printed as barcode and RFID code encoding on the table of distribution identification for 
Preventing risk thorough the electronic balance

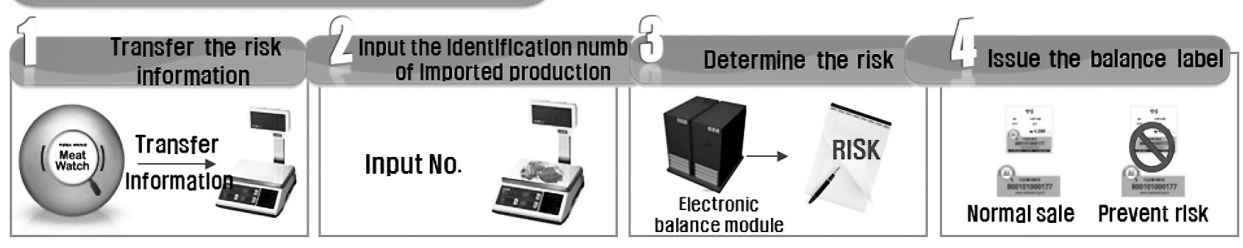

Preventing risk thorough the credit Gard terminal

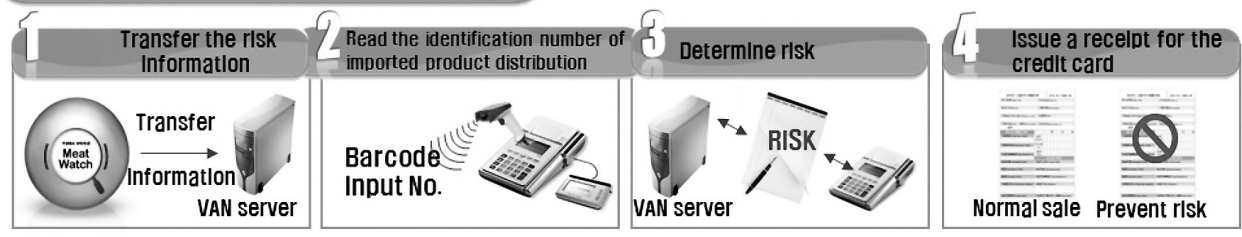

Fig. 10. Examples of the system to prevent risk beef sales (Electronic balance and a credit card terminal).

Table 2. The RIFD standard code for distribution identification for the imported good

\begin{tabular}{ccccc}
\hline Meaning & Header & Partition & Serial Number & Total \\
\hline Standard code & $\begin{array}{c}\text { Identification } \\
\text { value from the } \\
\text { institute }\end{array}$ & $\begin{array}{c}\text { Serial Number } \\
\text { Composition } \\
\text { Meaning }\end{array}$ & $\begin{array}{c}\text { Distribution identification } \\
\text { number for the imported good, } \\
\text { Serial number on the box and } \\
\text { other identification } \\
\text { information }\end{array}$ & \\
\hline Type & Char & Binary & Binary & 112bit \\
\hline Size & 24bit & 2bit & 86bit & \\
\hline Remark & $\begin{array}{c}\text { Fixed value } \\
\text { ('MAF') }\end{array}$ & & & \\
\hline
\end{tabular}

Table 3. Detail contents of the distribution traceability management system for imported beef and RFID management system

\begin{tabular}{|c|c|c|}
\hline & Ianaging functions & Detail contents \\
\hline \multirow{2}{*}{$\begin{array}{l}\text { Meaning } \\
\text { Type }\end{array}$} & Managing supply facilities & - Search, registration, modification, deletion for supplied facilities \\
\hline & $\begin{array}{l}\text { Managing portable reader } \\
\text { data }\end{array}$ & $\begin{array}{l}\text { - Search, registration, modification, deletion of data related to the portable } \\
\text { reader }\end{array}$ \\
\hline \multirow{3}{*}{ Work } & $\begin{array}{l}\text { Managing warehousing/ } \\
\text { delivery information }\end{array}$ & - Manage warehousing/delivery information by using the portable reader \\
\hline & Code mapping & $\begin{array}{l}\text { - Mapping the basic information and weight to distribution identification } \\
\text { number for the imported good with a serial number }\end{array}$ \\
\hline & Using supply facilities & $\begin{array}{l}\text { - Check the current usage of the electronic balance and the portable } \\
\text { reader }\end{array}$ \\
\hline \multirow{2}{*}{$\begin{array}{l}\text { Issuing } \\
\text { a tag }\end{array}$} & Present state of issuing a tag & - Inquire information of issuing a tag in each quarantine station \\
\hline & Statistics for issuing a tag & $\begin{array}{l}\text { - Cumulative, average, maximum, and minimum number of issuing tags per } \\
\text { each quarantine station }\end{array}$ \\
\hline $\begin{array}{l}\text { Attaching } \\
\text { a tag }\end{array}$ & Guideline for attaching a tag & $\begin{array}{l}\text { - Registration, modification, deletion, and inquiry for guideline information } \\
\text { related to attaching a tag } \\
\text { - Provide a guideline document about attaching a tag (guidance with a } \\
\text { separate document) }\end{array}$ \\
\hline
\end{tabular}

imported goods on the basis of the standard for barcode and RFID technology. These barcode and RFID code can be recognized by Automatic Identification and Data Capture (AIDC) technology. The RIFD standard code for distribution identification for imported goods is composed of Header, Partition, and Serial Number, thus, the overall size of the code is 112 bit (Table 2). In addition, PDA application system was introduced for processing collected data effectively and supporting works. Detail contents of the distribution traceability manage- 
Table 4. Linked systems to the distribution traceability management system for imported beef and main information

\begin{tabular}{clc}
\hline \multicolumn{1}{c}{ System } & \multicolumn{1}{c}{ Main information of data in the system } & \multicolumn{1}{c}{ Provider } \\
\hline $\begin{array}{c}\text { Livestock administration } \\
\text { information system }\end{array}$ & $\begin{array}{l}\text { Permission for raising livestock, address of } \\
\text { farms, permission of livestock processing, } \\
\text { permission of storing livestock products, and } \\
\text { markets for livestock in the area }\end{array}$ & $\begin{array}{c}\text { Ministry for Food, Agriculture, } \\
\text { Forestry and Fisheries (MIFAFF) }\end{array}$ \\
& $\begin{array}{l}\text { Information for country code, bonded } \\
\text { facilities, quarantine station, oversea } \\
\text { processing company, item, company, import } \\
\text { report for livestock, butcher house, processing } \\
\text { company, import declaration, and imported } \\
\text { part }\end{array}$ & $\begin{array}{c}\text { National Veterinary Research \& } \\
\text { Quarantine Service (NVRQS) }\end{array}$ \\
$\begin{array}{c}\text { Dection and quarantion system } \\
\text { imported livestock sales }\end{array}$ & $\begin{array}{l}\text { Permission of sales for livestock, and address } \\
\text { of livestock selling company }\end{array}$ & $\begin{array}{c}\text { National Veterinary Research \& } \\
\text { Quarantine Service (NVRQS) }\end{array}$ \\
Origin management & $\begin{array}{l}\text { Information livestock management from the } \\
\text { origin }\end{array}$ & $\begin{array}{c}\text { National Agricultural Products Quality } \\
\text { Management Service (NAQS) }\end{array}$ \\
\hline
\end{tabular}

ment system for imported beef and RFID management system are described in Table 3.

\section{Linkage of information with relevant informa- tion systems}

It is very important to link and share information in establishing a public system. Many information systems have been establishing in a year. If linkage is not considered among those systems, and each system is established separately and uses a code for each one independently, it is not expected to utilize information effectively through the linkage of information among systems in the future. Therefore, the $\mathrm{u}$-IT based distribution traceability management system for imported beef increased efficiency of utilizing information by linking several relevant systems such as livestock administration information system, inspection and quarantine information system, declaration system for imported livestock sales, and origin management system (Table 4).

\section{CONCLUSION AND SUMMARY}

We developed a distribution traceability management system for imported beef by using a recent $\mathrm{u}-\mathrm{IT}$, and this system can be used by several interest groups (public officials in charge of this issue in related institutes, sellers, and institutes for consumers).

Under the global trade environments, import and export of goods are unavoidable. The developed distribution traceability management system for imported beef can help to build trust for the food safety managements from consumers. The integrated management of transactions from import to sales under the system made fast recall possible in case of risk beef. In addition, several facilities for preventing risk beef sales were prepared such as registering risk beef transactions, providing information, sending risk beef information rapidly, and introducing systems for blocking beef sales (electronic balance and credit card terminal).

There might be some difficulties in operating this system because there are many distribution pathways of imported beef in Korea, and some related salesmen might not be able to afford the system. However, operation of the system will be started from December 2010 officially after the law about cow and beef traceability is enforced. All imported beef will be systemically managed from the stage of import/inspection, and the computerization of all transactions of importer will be required. Then, the distribution traceability for imported beef will be managed systematically and reliably. It is expected that more importers and salesmen in wrapping meat industry and in livestock markets will get involved in using the system.

\section{REFERENCES}

Duk Huh, 2006 Traceability of cattle in major countries, CREI, Agriculture issues an article

CRIC, 2009, National food safety survey, Research reports

Distribution of cattle beef traceability law, 2010

Gallup Korea, 2010 Traceability of imported beef, Survey reports

MIFAFF. 2010a u-IT based distribution traceability management system for imported beef, research report

MAF, 2005 A study on establishing traceability system in livestock production and marketing channel, Research reports

MIFAFF, 2010b A study of u-IT business diffusion policies in the agriculture, fisheries, livestock industry, Research reports

http://www.mtrace.go.kr, 2010 Beef traceability management system

http://www.meatwatch.go.kr, $2010 \quad$ Imported beef traceability management system 